\title{
KAJIAN KEBERLANJUTAN PENGELOLAAN BUDIDAYA IKAN BANDENG DI GRESIK
}

\section{Sustainbility Study of Milkfish Farming Management in Gresik}

\author{
"Irwan Muliawan, Achmad Zamroni dan Fatriyandi Nur Priyatna \\ Pusat Penelitian Sosial Ekonomi Kelautan dan Perikanan \\ Gedung Balitbang KP I Lt. 4 \\ Jalan Pasir Putih Nomor 1 Ancol Timur, Jakarta Utara, Indonesia \\ Telp: (021) 64711583 Fax: 64700924 \\ Diterima tanggal: 24 Pebruari 2016 Diterima setelah perbaikan: 23 Mei 2016 \\ Disetujui terbit: 6 Juni 2016 \\ *email: irwan_muliawan@yahoo.com
}

\begin{abstract}
ABSTRAK
Perikanan budidaya bandeng telah lama menjadi bagian dari usaha masyarakat pesisir. Permasalahan pengelolaan budidaya bandeng semakin hari menjadi semakin kompleks. Permasalahan yang timbul pun muncul dari berbagai aspek. Sedikitnya ada lima aspek yang terlibat: ekologi, ekonomi, sosial, teknologi dan kelembagaan. Olehnya itu, kajian singkat (rapid) terhadap pengelolaan perikanan budidaya bandeng dilakukan untuk melihat keterkaitan lima aspek tersebut. Gresik adalah salah satu sentra produksi ikan bandeng utama di Indonesia, menjadi cuplikan dalam mengkaji keberlanjutan pengelolaan ikan bandeng yang dianggap dapat mewakili pengelolaan bandeng secara umum. Dengan penggunakan analisis Rapid Appraisal of Fisheries (Rapfish) kajian generik pengelolaan bandeng dapat diuraikan tingkat keberlanjutan pengelolaan perikanan budidaya bandeng berdasarkan dimensi (aspek) dan atribut (variable) yang dikembangkan. Dihasilkan bahwa keberlanjutan pengelolaan perikanan budidaya bandeng berada pada kondisi cukup (cenderung buruk) sehingga perlu re-orientasi pengelolaan. Aspek yang perlu perhatian adalah melakukan penyeimbangan aspek ekologi dan ekonomi, dengan mengurangi tekanan pada ekologi pesisir dan memperbanyak tujuan pasar / orientasi pemasaran produk bandeng.
\end{abstract}

Kata Kunci: keberlanjutan, pengelolaan, ikan bandeng

\begin{abstract}
Milkfish aquaculture has been long part of the efforts business of coastal communities. The problem in milkfish aquaculture management is becoming increasingly complex. The problems arose from various aspects. There was at least five aspects involved: ecological, economic, social, technological and institutional. Therefore, a brief assessment (rapid) for the management of aquaculture of milkfish was done to see how the five aspects. By using an analysis Rapid Appraisal of Fisheries (Rapfish) described the level of sustainability of aquaculture of that milkfish by dimensions (aspects) and attributes (variables) were developed. Result showed sustainability of aquaculture of milkfish in condition enough (likely worse) that need re-orientation of management. Need to do a balancing ecological and economic aspects, by reducing the pressure on the mangrove ecosystem and increase market destination/ market oriented for milkfish product.
\end{abstract}

Keywords: sustainability, management, milk fish

\section{PENDAHULUAN}

Pengembangan ikan bandeng sebagai salah satu pendorong peningkatan produksi perikanan perlu dicermati secara rasional. Potensi lahan yang cukup luas merupakan modal penting, namun masih terdapat kendala pada pertumbuhan penduduk, sehingga lahan konversi lahan tidak terhindarkan. Pengembangan luas lahan tambak budidaya bandeng di Indonesia banyak terbentur dengan konversi lahan. Konversi lahan tambak ke penggunaan lainnya, berdampak pada ekstensifnya pembukaan lahan mangrove untuk lahan pertambakan baru. Tabel 1 menunjukkan perkembangan luas lahan tambak di Indonesia dalam kurun waktu 2005-2015. Terlihat luas lahan tambak berfluktuasi, artinya terjadi pembukaan lahan baru dan konversi untuk penggunaan lainnya. 


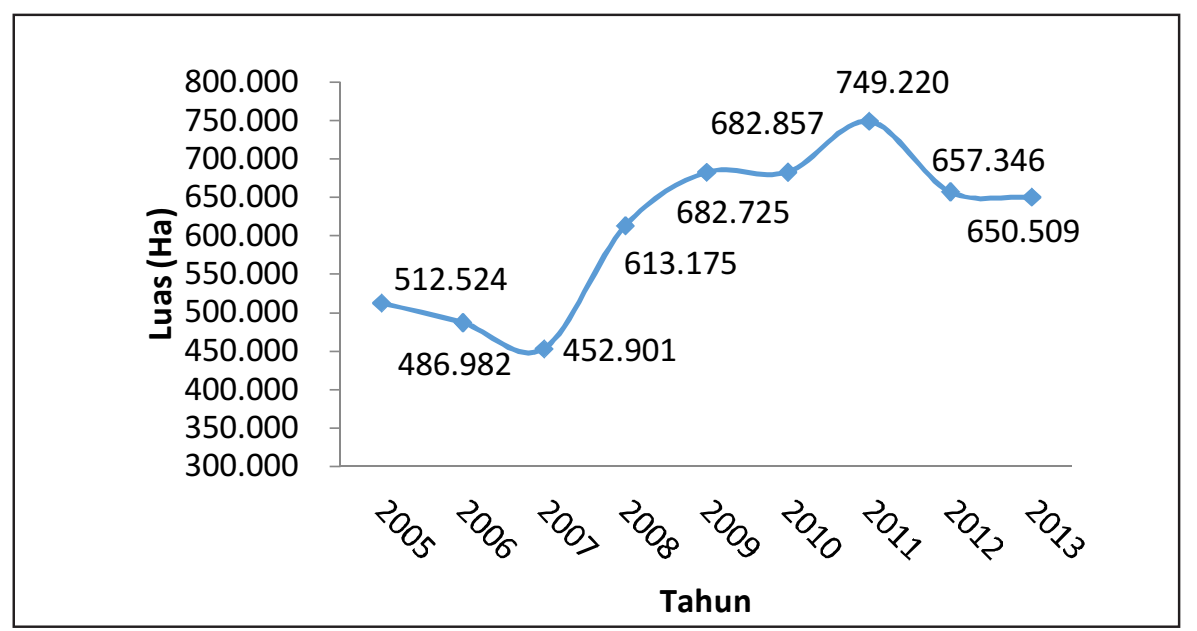

Sumber: BPS, 2015/Source: BPS, 2015

Gambar 1. Grafik Perkembangan Luas Lahan Tambak di Indonesia, 2005-2013

Figure 1. The Development Land Area of Ponds Graph in Indonesia, 2005-2013

Namun secara sosial budaya ikan bandeng adalah jenis ikan konsumsi yang tidak asing bagi masyarakat. Bandeng merupakan hasil tambak, budidaya ikan ini mula-mula merupakan pekerjaan sampingan bagi nelayan yang tidak dapat pergi melaut. Meski pendapatan petambak yang cenderung fluktuatif, sebagai sampel, pada petambak di Gersik. Pendapatan petani ikan/udang juga mengalami hal yang sama seperti pendapatan nelayan. Perkembangan pendapatan petani ikan dapat dilihat pada Tabel 1.

Kondisi diatas merupakan gambaran terhadap penting menelaah lebih lanjut keberlanjutan pengelolaan perikanan budidaya bandeng di Indonesia. Hal ini pentung untuk memberikan mencari strategi yang sesuai untuk agar tujuan pembangunan perikanan berkelanjutan dan mandiri.

Konsep pembangunan berkelanjutan sebenarnya telah menjadi agenda Internasional dalam pertemuan komisi dunia untuk pembangunan dan lingkungan (WCED = World Commission on Environmental and Development) tahun 1987 dan telah dikonfirmasi oleh negara-negara di dunia menjadi prioritas internasional dalam konvensi PBB untuk lingkungan dan pembangunan (UNCED $=$ United Nation Convention on Environment and Development, 1992). Kemudian dalam agenda 21 konsep tersebut dibahas dalam Commission on Sustainable Development (CSD) yang mengembangkan indikator pembangunan berkelanjutan dalam skala yang beragam. Penekanan pada perikanan tangkap yang mempunyai masalah pemanfaatan sumberdaya yang tidak lestari menjadi prioritas utama (FAO, 2001).

Alder et al., (2002) mengatakan bahwa sampai sekarang masih terjadi diskusi yang hangat tentang istilah keberlanjutan (sustainability) dan bagaimana cara mengukurnya. Namun demikian

Tabel 1. Perkembangan pendapatan petani ikan tahun 2008-2012.

Table 1. Fish farmer income trends in Year 2008 - 2012.

\begin{tabular}{ccc}
\hline Tahun/Year & $\begin{array}{c}\text { Pendapatan rata-rata petani ikan } \\
\text { (Rp)/Tahun/ Farmer Fish Average } \\
\text { Income (IDR)/Year }\end{array}$ & $\begin{array}{c}\text { Prosentase kenaikan atau penurunan } \\
\text { dibanding tahun sebelumnya (\%)/ } \\
\text { The percentage of increase or decrease } \\
\text { from the previous year (\%) }\end{array}$ \\
\hline 2008 & 14.999 .950 & 26,58 \\
2009 & 14.500 .000 & 3,33 \\
2010 & 21.000 .000 & 44,83 \\
2011 & 22.200 .000 & 5,71 \\
2012 & 25.576 .000 & 15,21 \\
\hline
\end{tabular}

Sumber: laporan tahunan Dinas Kelautan, Perikanan dan Peternakan, Gresik 2013/

Source: The annual report of Marine, Fisheries and Livestock Department, Gresik 2013 
secara umum terdapat satu kesepakatan bahwa keberlanjutan harus mencakup komponen ekologi, ekonomi, sosial, teknologi dan etika (Antune and Santos, 1999; Costanza et al, 1999, Garcia, Staples and Chesson, 2000 yang diacu dalam Alder et al., 2000).

Konsep pembangunan berkelanjutan juga dapat dilihat dalam konsep FAO Council (1988) yang diacu dalam FAO (2001) sebagai pengelolaan dan perlindungan sumberdaya alam dan perubahan orientasi teknologi dan kelembagaan dalam beberapa cara yang dapat mendukung pemenuhan kebutuhan generasi sekarang dan yang akan datang. Pembangunan berkelanjutan berusaha untuk melindungi tanah, air, tumbuhan serta sumberdaya genetis hewan, yang tidak menurunkan kualitas lingkungan di mana secara teknis tepat, secara ekonomis berguna, dan secara sosial dapat diterima.
Tulisan ini mencoba melakukan kajian keberlanjutan pengelolaan perikanan budidaya bandeng dengan tujuan menggali aspek ekologi, ekonomi, sosial, teknologi dan etika dalam pengelolaan perikanan.

\section{METODOLOGI}

\section{Atribut dan skala yang digunakan}

Hasil penelitian di lapang baik dengan menggunakan data primer (wawancara, pengamatan, dan diskusi dengan stakeholder) maupun data sekunder ditemukan 44 atribut yang terpenuhi untuk 5 dimensi dalam analisis Rapfish. $\mathrm{Ke}-28$ atribut tersebut terbagi ke dalam masingmasing dimensi yaitu 4 atribut ekologi, 9 atribut ekonomi, 5 atribut sosial, 4 atribut teknologi, dan 6 atribut kelembagaan.

Tabel 1. Atribut dan Skala yang Digunakan pada Tiap Dimensi. Table 1. Attributes and Scale Used in Every Dimension.

\begin{tabular}{|c|c|c|c|c|c|}
\hline No. & Atribut/Attribute & Pilihan skor & Baik/Good & Buruk/Bad & Keterangan/Description \\
\hline 1 & \multicolumn{5}{|c|}{ Dimensi Ekologi/Ecology Dimension } \\
\hline 1.1 & $\begin{array}{l}\text { Tekanan pemanfaatan } \\
\text { terhadap perairan/ }\end{array}$ & $0 ; 1 ; 2$ & 0 & 2 & $\begin{array}{l}\text { Susilo (2003) : } \\
\text { (0) kurang; (1) sedang; (2) tinggi }\end{array}$ \\
\hline 1.2 & $\begin{array}{l}\text { Perubahan ukuran } \\
\text { ikan permintaan ikan dan } \\
\text { ikan indukan }\end{array}$ & $0 ; 1 ; 2$ & 0 & 2 & $\begin{array}{l}\text { Modifikasi Rapfish : (0) tetap; } \\
\text { (1) berkurang; (2) bertambah }\end{array}$ \\
\hline 1.3 & $\begin{array}{l}\text { Pemanfaatan } \\
\text { pariwisata / }\end{array}$ & $0 ; 1 ; 2 ; 3$ & 3 & 0 & $\begin{array}{l}\text { Susilo }(2003) \text { : (0) melebihi } \\
\text { kapasitas atau tidak ada; } \\
\text { (1) rendah; (2) sedang; } \\
\text { (3) optimal }\end{array}$ \\
\hline 1.4 & $\begin{array}{l}\text { Tekanan terhadap } \\
\text { lingkungan darat } \\
\text { (mangrove) }\end{array}$ & $0 ; 1 ; 2$ & 0 & 2 & $\begin{array}{l}\text { Modifikasi Rapfish : (0) kurang; } \\
\text { (1) sedang; (2) tinggi }\end{array}$ \\
\hline 2 & \multicolumn{5}{|c|}{ Dimensi Ekonomi/ Economics Dimension } \\
\hline 2.1 & Keuntungan & $\begin{array}{l}0 ; 1 ; 2 ; \\
3 ; 4\end{array}$ & 0 & 4 & $\begin{array}{l}\text { Rapfish : (0) sangat } \\
\text { menguntungkan; (1) } \\
\text { menguntungkan; (2); sedikit } \\
\text { menguntungkan (3) mendekati } \\
\text { impas atau kembali modal; } \\
\text { (4) merugi }\end{array}$ \\
\hline 2.2 & $\begin{array}{l}\text { Kontribusi perikanan } \\
\text { terhadap PDRB }\end{array}$ & $0 ; 1 ; 2$ & 2 & 0 & $\begin{array}{l}\text { Rapfish : (0) rendah; (1) sedang; } \\
\text { (2) tinggi }\end{array}$ \\
\hline 2.3 & $\begin{array}{l}\text { Pendapatan per } \\
\text { Kapita }\end{array}$ & $0 ; 1 ; 2 ; 3$ & 3 & 0 & $\begin{array}{l}\text { Modifikasi Rapfish : (0) sangat } \\
\text { jauh di bawah Kebutuhan } \\
\text { Hidup Minimum (KHM); (1) di } \\
\text { bawah KHM; (2) seimbang atau } \\
\text { mendekati KHM; (3) di atas KHM }\end{array}$ \\
\hline
\end{tabular}




\begin{tabular}{|c|c|c|c|c|c|}
\hline No. & Atribut/Attribute & Pilihan skor & Baik/Good & Buruk/Bad & Keterangan/Description \\
\hline 2.4 & $\begin{array}{l}\text { Kepemilikan } \\
\text { (penerima keuntungan } \\
\text { dari kepemilikan) }\end{array}$ & $0 ; 1 ; 2$ & 0 & 2 & $\begin{array}{l}\text { Rapfish : (0) pemilik lokal; } \\
\text { (1) pemilik lokal dan non lokal; (2) } \\
\text { pemilik non lokal }\end{array}$ \\
\hline 2.5 & $\begin{array}{l}\text { Alternatif pekerjaan dan } \\
\text { pendapatan }\end{array}$ & $0 ; 1 ; 2$ & 2 & 0 & $\begin{array}{l}\text { Rapfish : (0) tidak ada; (1) } \\
\text { ada sedikit; (2) ada banyak }\end{array}$ \\
\hline 2.6 & $\begin{array}{l}\text { Lokasi tujuan } \\
\text { atau orientasi } \\
\text { pemasaran perikanan }\end{array}$ & $0 ; 1 ; 2$ & 0 & 2 & $\begin{array}{l}\text { Rapfish : (0) pasar lokal; } \\
\text { (1) pasar nasional; (2) } \\
\text { pasar internasional }\end{array}$ \\
\hline 2.7 & $\begin{array}{l}\text { Penerimaan } \\
\text { relatif }\end{array}$ & $0 ; 1 ; 2$ & 2 & 0 & $\begin{array}{l}\text { (0) rendah; (1) sedang atau } \\
\text { mendekati UMP; (2) tinggi }\end{array}$ \\
\hline 2.8 & $\begin{array}{l}\text { Transfer } \\
\text { keuntungan antara } \\
\text { orang / pelaku ekonomi } \\
\text { lokal dan } \\
\text { / pelaku ekonomi luar } \\
\text { daerah }\end{array}$ & $0 ; 1 ; 2$ & 0 & 2 & $\begin{array}{l}\text { Susilo (2003) : (0) } \\
\text { terutama berada di orang lokal; } \\
\text { (1) seimbang antar orang lokal } \\
\text { dan orang luar; (2) keuntungan } \\
\text { lebih banyak diperoleh orang } \\
\text { luar }\end{array}$ \\
\hline 2.9 & $\begin{array}{l}\text { Penyerapan } \\
\text { tenaga kerja labour } \\
\text { absorption }\end{array}$ & $0 ; 1 ; 2$ & 2 & 0 & $\begin{array}{l}\text { Modifikasi Rapfish : (0) rendah; } \\
\text { (1) sedang; (2) tinggi }\end{array}$ \\
\hline 3 & \multicolumn{5}{|c|}{ Dimensi Sosial/ Social Dimension } \\
\hline 3.1 & $\begin{array}{l}\text { Pengetahuan lingkungan } \\
\text { perikanan }\end{array}$ & $0 ; 1 ; 2$ & 2 & 0 & $\begin{array}{l}\text { Rapfish : (0) sangat minim; } \\
\text { (1) cukup; (2) sangat luas }\end{array}$ \\
\hline 3.2 & Tingkat pendidikan & $0 ; 1 ; 2$ & 2 & 0 & $\begin{array}{l}\text { Rapfish, dibandingkan } \\
\text { terhadap rata-rata penduduk: } \\
\text { (0) rendah; (1) sedang; } \\
\text { (2) tinggi }\end{array}$ \\
\hline 3.3 & Konflik & $0 ; 1 ; 2$ & 0 & 3 & $\begin{array}{l}\text { (0) tidak berpengaruh; } \\
\text { (1) biasa; ( } 2 \text { ) berat; ( } 3 \text { ) Sangat } \\
\text { berat }\end{array}$ \\
\hline 3.4 & $\begin{array}{l}\text { Partisipasi keluarga dalam } \\
\text { Pemanfaatan sumberdaya } \\
\text { Perikanan }\end{array}$ & $0 ; 1$ & 1 & 0 & $\begin{array}{l}\text { Modifikasi Rapfish : } \\
\text { (0) tidak ada; (1) ada }\end{array}$ \\
\hline 3.5 & $\begin{array}{l}\text { Frekuensi pertemuan antar } \\
\text { warga berkaitan pengelolaan } \\
\text { sumberdaya perikanan }\end{array}$ & $0 ; 1 ; 2$ & 2 & 0 & $\begin{array}{l}\text { Susilo (2003): (0) tidak } \\
\text { pernah ada; (1) sekali dalam } \\
5 \text { tahun; (2) lebih dari sekali } \\
\text { dalam setahun }\end{array}$ \\
\hline
\end{tabular}

\section{Dimensi Teknologi / Technology Dimension}

\begin{tabular}{|c|c|c|c|c|c|}
\hline 4.1 & Teknologi budidaya & $0 ; 1 ; 2$ & 0 & 2 & $\begin{array}{l}\text { Rapfish : (0) tradisional } \\
\text { (1) semi intensif; (2) intensif }\end{array}$ \\
\hline 4.2 & Siklus panen & $0 ; 1 ; 2$ & 0 & 2 & $\begin{array}{l}\text { Modifikasi Rapfish: }(0)<4 \text { bulan } \\
\text { jam; (1) } 4-6 \text { bulan; }(2)>6 \text { bulan }\end{array}$ \\
\hline 4.3 & $\begin{array}{l}\text { Ukuran tambak per } \\
\text { petak }\end{array}$ & $0 ; 1 ; 2$ & 0 & 2 & $\begin{array}{l}\text { Modifikasi Rapfish: }(0)<100 \mathrm{~m}^{2} \text {; } \\
\text { (1) } 100-300 \mathrm{~m} 2 ;(2)>300 \mathrm{~m} 2\end{array}$ \\
\hline 4.4 & $\begin{array}{l}\text { Penanganan } \\
\text { pasca panen }\end{array}$ & $0 ; 1 ; 2$ & 2 & 0 & $\begin{array}{l}\text { Rapfish : (0) tidak ada; } \\
\text { (1) sedikit; (2) banyak }\end{array}$ \\
\hline
\end{tabular}




\begin{tabular}{|c|c|c|c|c|c|}
\hline No. & Atribut/Attribute & Pilihan skor & Baik/Good & Buruk/Bad & Keterangan/Description \\
\hline 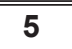 & \multicolumn{5}{|c|}{ Dimensi Kelembagaan/ Institutional Dimension } \\
\hline 5.1 & $\begin{array}{l}\text { Ketersediaan peraturan } \\
\text { formal dan Informal } \\
\text { pengelolaan perikanan }\end{array}$ & $0 ; 1 ; 2$ & 2 & 0 & $\begin{array}{l}\text { Susilo (2003) : (0) kurang; } \\
\text { (1) cukup; (2) banyak }\end{array}$ \\
\hline 5.2 & $\begin{array}{l}\text { Ketersediaan Organisasi } \\
\text { pengembangan budidaya } \\
\text { di lokasi }\end{array}$ & $0 ; 1 ; 2$ & 2 & 0 & $\begin{array}{l}\text { Susilo (2003) : (0) tidak } \\
\text { ada; (1) sedikit atau jarang } \\
\text { berada di lokasi; (2) banyak atau } \\
\text { sering berada di lokasi }\end{array}$ \\
\hline 5.3 & $\begin{array}{l}\text { Demokrasi } \\
\text { dalam penentuan } \\
\text { kebijakan / }\end{array}$ & $0 ; 1 ; 2$ & 2 & 0 & $\begin{array}{l}\text { Susilo (2003) : (0) tidak } \\
\text { demokratis; (1) kadang- kadang } \\
\text { demokratis; (2) sangat demokratis }\end{array}$ \\
\hline 5.4 & $\begin{array}{l}\text { Peranan kelembagaan } \\
\text { formal yang mendukung } \\
\text { pengelolaan sumberdaya } \\
\text { perikanan }\end{array}$ & $0 ; 1 ; 2 ; 3$ & 3 & 0 & $\begin{array}{l}\text { (0) tidak ada; }(1) \text { ada tapi } \\
\text { tidak berperan; }(2) \text { cukup } \\
\text { berperan; (3) sangat berperan }\end{array}$ \\
\hline 5.5 & $\begin{array}{l}\text { Ketersediaan dan peran } \\
\text { tokoh masyarakat lokal }\end{array}$ & $0,1,2$ & 2 & 0 & $\begin{array}{l}\text { (0) tidak ada } \\
\text { (1) ada, kurang berperan } \\
\text { (2) ada, cukup berperan }\end{array}$ \\
\hline 5.6 & $\begin{array}{l}\text { Peranan kelembagaan } \\
\text { lokal (informal) yang } \\
\text { mendukung pengelolaan } \\
\text { sumber daya perikanan }\end{array}$ & $0,1,2$ & 2 & 0 & $\begin{array}{l}\text { (0) tidak ada } \\
\text { (1) ada, kurang } \\
\text { (2) ada cukup berperan }\end{array}$ \\
\hline
\end{tabular}

Sumber: Kavanagh (2001), Pitcher, T. J. and D. Preiskhot (2001) and Susilo (2003).

\section{Analisis data}

Metode penelitian yang digunakan dalam penelitian ini mengacu pada teknik Rapfish (Rapid Appraissal for Fisheries) adalah teknik yang dikembangkan oleh University of British Columbia Canada suatu teknik analisis untuk mengevaluasi sustainability dari perikanan secara multidisipliner. Keluaran analisis Rapfish, yaitu status keberlanjutan perikanan ditinjau dari berbagai dimensi secara komprehensif yang menyangkut dimensi ekologi, ekonomi, sosial, teknologi dan hukum serta kelembagaan, adalah dasar untuk menyusun strategi pengelolaan selanjutnya berdasarkan atribut-atribut sensitif yang mempengaruhi status perikanan pada dimensi yang dianalisis.

Prosedur analisis dengan teknik Rapfish ini akan melalui beberapa tahapan sebagai berikut:

1. Analisis terhadap data perikanan lokasi studi melalui data statistik.

2. Analisis data pengamatan lapangan dan studi literature.
3. Melakukan skoring aspek keberlanjutan perikanan.

4. Melakukan analisis multidimensional scaling (MDS) dengan modul macro rapfish.

5. Melakukan rotasi untuk menentukan posisi perikanan pada ordinasi bad dan good.

6. Melakukan sensitivity analysis (Leverage analysis) dan Monte Carlo analysis untuk memperhitungkan aspek ketidakpastian.

Dengan teknik Rapfish ini dapat dilihat performa perikanan tangkap di wilayah studi di mana masing-masing dimensi, hasilnya digambarkan dalam bentuk axis. Axis horizontal menunjukkan perbedaan dari campuran skor atribut di antara perikanan yang dievaluasi. Analisis ordinasi menunjukkan variasi keberlanjutan antar alat tangkap. Keragaan (variasi) di antara alat tangkap untuk setiap aspek dapat jugatergambarkan skornya. Dari skoring tersebut dapat dideterminasi status perikanan dan keberlanjutannya. 
Teknik analisis Monte Carlo digunakan untuk mengevaluasi dampak kesalahan dari kesalahan acak (random error) terhadap seluruh aspek. Dalam penelitian ini digunakan metode analisis Monte Carlo algoritma dengan metode scatter plot yang menunjukkan ordinasi dari setiap aspek (Fauzi, A. dan S. Anna. 2002).

\section{HASIL DAN PEMBAHASAN}

\section{Ekologi}

Hasil simulasi tersebut menunjukkan bahwa kegiatan perikanan budidaya bandeng banyak mengalami gangguan (perturbation) yang ditunjukkan oleh plot yang menyebar. penyebaran ini menjadi indikasi sedikitnya peluang bagi masing-masing atribut untuk mengelompok secara keseluruhan sangat kecil. Sehingga tiap atribut dalam dimensi ekologi memiliki karakteristik yang berbeda.

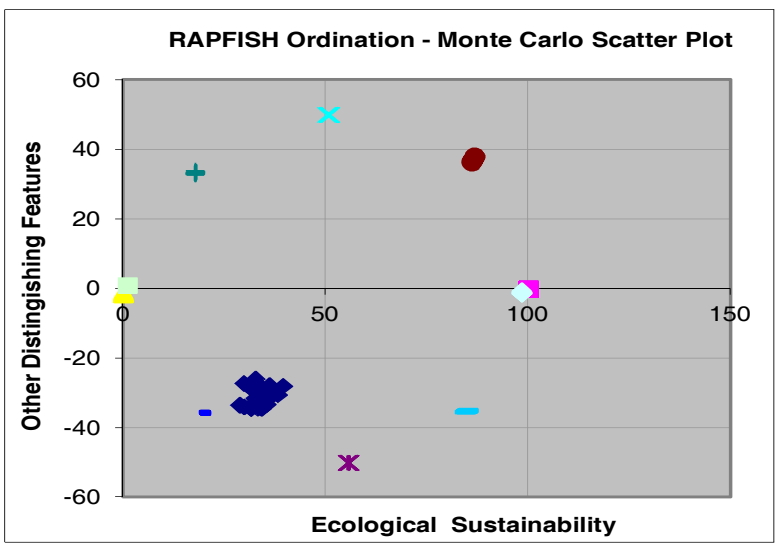

Gambar 2. Hasil Simulasi Monte Carlo untuk Dimensi Ekologi.

Figure 2. Simulation Monte Carlo Results for Ecology Dimension.

Analisis sensitivitas pada dimensi ekologi dengan metode analisis leverage pada Rapfish memperlihatkan bahwa atribut Tekanan terhadap lingkungan darat (Mangrove) merupakan atribut yang sangat berpengaruh terhadap keberlanjutan perikanan budidaya bandeng. Perubahan sedikit saja pada atribut ini akan berdampak besar terhadap status keberlanjutan pada dimensi ekologi. Hal ini dapat dilihat dari nilai root mean square change (Gambar 2) terlihat bahwa ada tiga atribut utama dalam dimensi ekologi ini yang dominan menentukan keberlanjutan dimensi ekologi.

Lahan tambak secara teknis dikembangkan dengan mengkonversi lahan hutan mangrove karena lahan mangrove merupakan lahan yang kaya unsur hara dan nutrien. Dengan demikian kawasan ini menjadi rentan terhadap alih fungsi dan alih pemanfaatan. Tekanan terhadap hutan mangrove perlu mendapat perhatian serius untuk menyeimbangkan ekosistem yang ada.

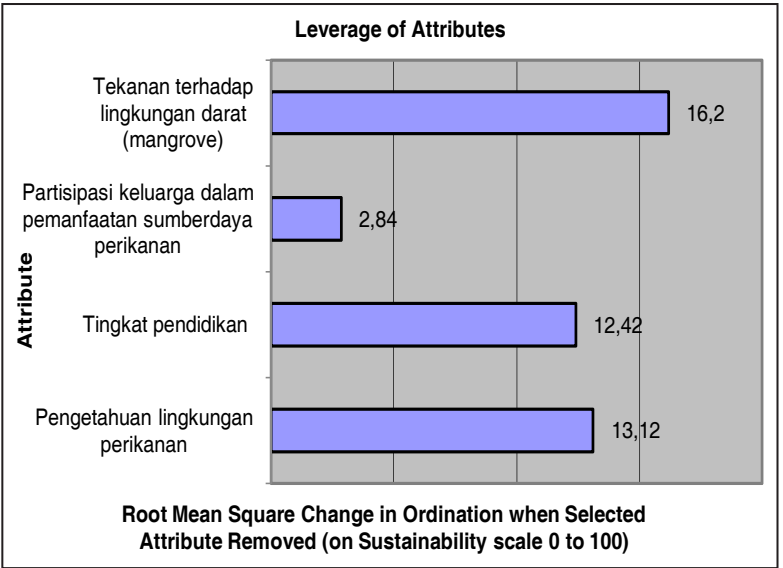

Gambar 3. Analisis Distribusi Sensitivitas Atribut pada Dimensi Ekologi.

Figure 3. Attribute Sensitivity Distribution Analysis on Ecology Dimension.

\section{Ekonomi}

Hasil analisis Monte Carlo dari dimensi ekonomi dapat dilihat pada Gambar 4. Hasil analisis tersebut menunjukkan bahwa kegiatan perikanan budidaya bandeng telah banyak mengalami gangguan (perturbation) yang ditunjukkan oleh plot yang menyebar pada gambar tersebut.

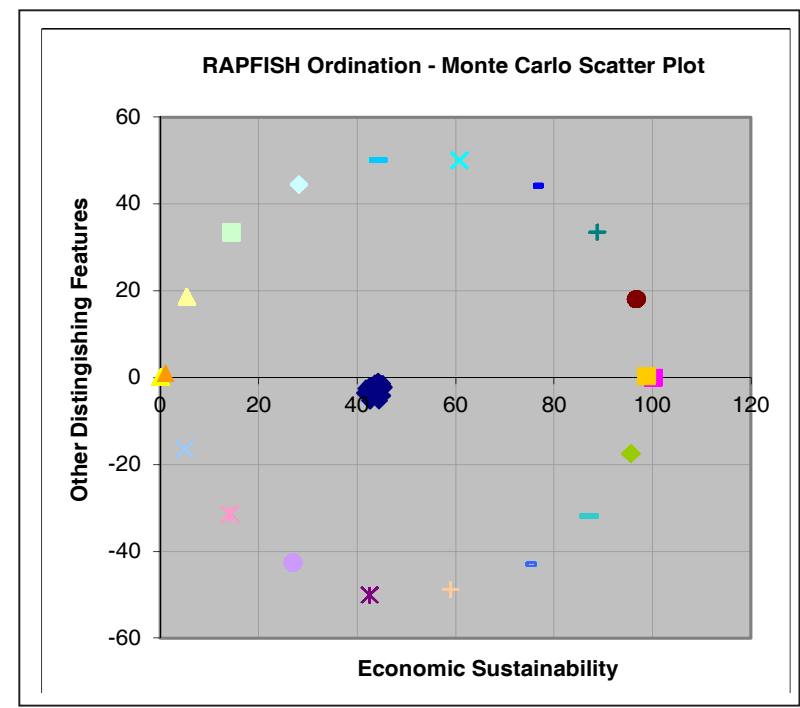

Gambar 4. Hasil Simulasi Monte Carlo untuk Dimensi Ekonomi.

Figure 4. Monte Carlo Simulation Results for the Economic Dimension. 
Pada dimensi ekonomi memperlihatkan bahwa atribut lokasi tujuan dan orientasi pemasaran dalam pengelolaan perikanan budidaya bandeng merupakan atribut yang dominan mempengaruhi skor keberlanjutan yang dikaji. Nilai root mean square change dari dimensi ekonomi pada analisis leverage dapat dilihat pada Gambar 5.

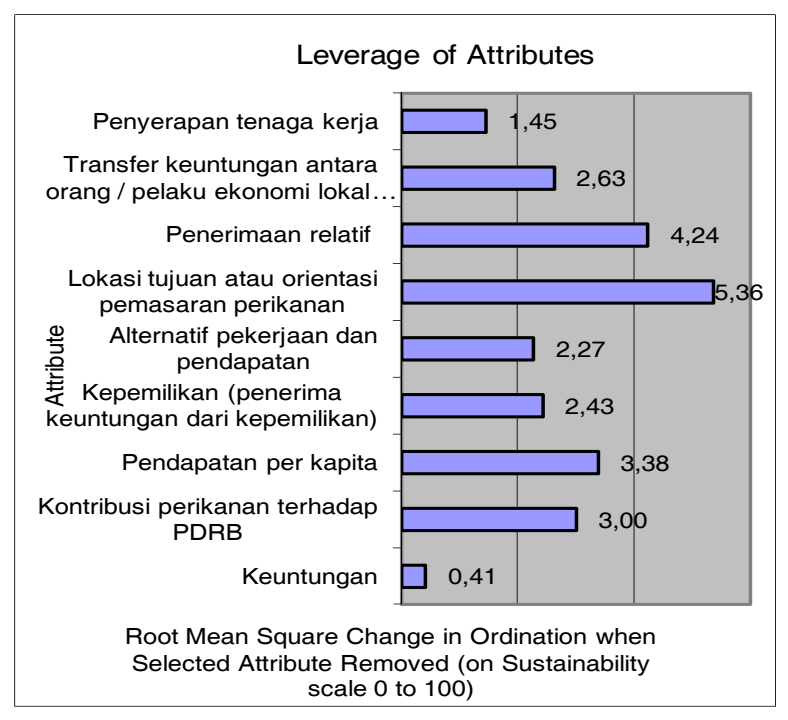

\section{Gambar 5. Analisis Distribusi Sensitivitas Atribut Pada Dimensi Ekonomi. \\ Figure 5. Attribute Sensitivity Distribution Analysis on Economics Dimension.}

Pihak petambak bandeng umumnya mengharapkan adanya kenaikan harga ikan bandeng di pasaran. Hal ini dirasakan perlu karena semakin besarnya biaya produksi ikan bandeng di tambak. dibanding dengan penerimaan yang peroleh dari hasil penjualan, petambak bandeng merasa minim. Menurut petambak tujuan pemasaran dan orientasi pasar terhadap produk bandeng perlu diubah. Tujuan yang langsung ke pengguna akhir atau konsumen merupakan pangsa pasar yang menjanjikan harga jual lebih baik. Dengan begitu orientasi pemasaran perikanan juga harus ikut menyesuaikan. Dapat dilihat bahwa atribut Lokasi tujuan atau orientasi pemasaran perikanan sangat sensitif dalam merubah dimensi ekonomi perikanan budidaya bandeng.

Kondisi ini memerlukan inovasi kebijakan yang berorientasi pada peningkatan kesejahteraan petambak bandeng. Hal ini sebenarnya cukup prospektifuntuk realisasikan, jika melihat permintaan ikan bandeng yang cenderung meningkat. Permintaan bandeng nasional mencapai 218.114 ton pada tahun 2014 (Tabel 2).

Sedangkan produksi bandeng untuk Gresik sebagai salah satu kawasan penghasil bandeng yang besar di Indonesia hanya mampu mensuplai 39.545 ton saja (Tabel 3).

Tabel 2. Permintaan Bandeng Nasional, 2004 - 2015.

Table 2. National Demand of Milkfish Commodity, 2004 -2015.

\begin{tabular}{cccc}
\hline $\begin{array}{c}\text { Tahun/ } \\
\text { Year }\end{array}$ & $\begin{array}{c}\text { Konsumsi/ } \\
\text { Consumption(Kg/kap) }\end{array}$ & $\begin{array}{c}\text { Penduduk/ } \\
\text { Population (juta) }\end{array}$ & $\begin{array}{c}\text { Permintaan/ } \\
\text { Demand (ton) }\end{array}$ \\
\hline 2010 & 1.862 & 238.519 & 206.670 \\
2011 & 1.869 & 240.289 & 208.198 \\
2012 & 1.877 & 242.119 & 209.778 \\
2013 & 1.897 & 246.950 & 213.946 \\
2014 & 1.918 & 251.781 & 218.114 \\
\hline
\end{tabular}

Sumber : BPS, 2015, diolah./Source: BPS, 2015, Processed

Tabel 3. Produksi Ikan Bandeng (Tambak) di Kabupaten Gresik, Tahun 2010 - 2014 (kg). Table 3. Milkfish Production (Ponds) Gresik Regency, 2010-2014 (kg).

\begin{tabular}{ccc}
\hline No & Tahun/Year & Bandeng \\
\hline 1 & 2010 & 16.838 .597 \\
2 & 2011 & 16.918 .394 \\
3 & 2012 & n.a \\
4 & 2013 & 39.911 .999 \\
5 & 2014 & 39.545 .462 \\
\hline
\end{tabular}

Sumber: Laporan tahunan Dinas Perikanan dan Kelautan Kabupaten Gresik, 2014.

Sourced: The annual report of Marine and Fisheries and Livestock Department Gresik, 2014 
Keterbatasan suplai menjadi anomali dalam melihat keterbatasan dan kesejahteraan para petambak. Seharusnya dengan meningkatnya permintaan dan dengan keterbatasan suplai menngakibatkan surplus produsen yang lebih tinggi. Sehingga produk bandeng seharusnya menjadi barang ekslusif. Anomali ini terjadi karena beragamnya pilihan produk terhadap pemenuhan kebutuhan protein hewani atau daging, selin itu produk ikan yang cepat rusak/busuk mengakibatkan keuntungan akhir tidak selalu berpihak pada petambak/nelayan.

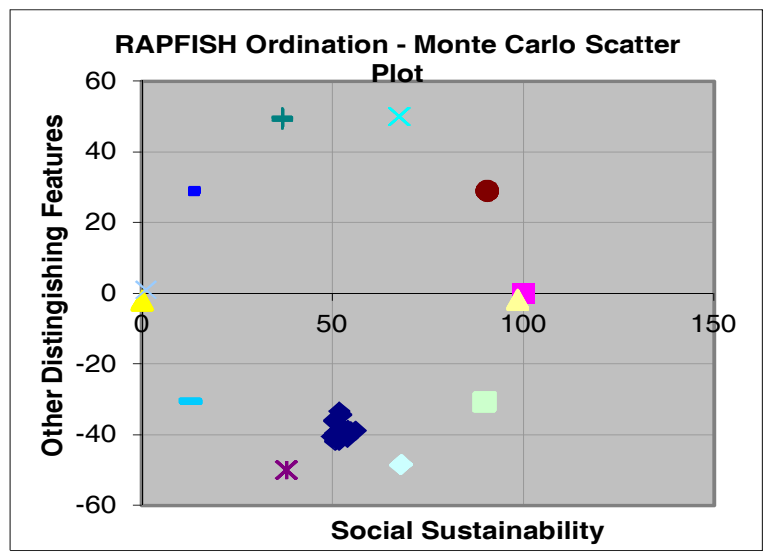

Gambar 6. Kestabilan Nilai Ordinasi Hasil Rapfish Dengan Monte Carlo Pada Dimensi Sosial.

\section{Figure 6. Stability of Rapfish Results Ordination Value With Monte Carlo in Social Dimension.}

Analisis leverage ini pada dasarnya sama seperti yang diterapkan pada dimensi lainnya yaitu untuk melihat bagaimana pengaruhnya terhadap skor keberlanjutan sosial apabila satu atribut dikeluarkan dari analisis sehingga bisa dilihat tingkat sensitivitas skor keberlanjutan sosial akibat dikeluarkannya satu atribut. Menurut Picther et al (1998), analisis sensitivitas atau analisis leverage dilakukan terhadap atribut-atribut masingmasing dimensi. Perhitungan dilakukan dengan metode stepwise yaitu dengan membuang setiap atribut secara berurutan satu persatu kemudian menghitung berapa nilai error atau Root Mean Square (RMS) tersebut dibandingkan dengan RMS yang dihasilkan pada saat seluruh atribut dimasukkan. Dalam statistik metode ini dikenal dengan metode JackKnife (Kavanagh, 2001).

Pada dimensi sosial mengindikasikan bahwa atribut Tingkat pendidikan dan Partisipasi keluarga dalam pemanfaatan sumberdaya perikanan merupakan atribut yang sangat berpengaruh terhadap nilai atau status keberlanjutan perikanan budidaya bandeng. Nilai root mean square change kedua atribut ini jauh lebih tinggi dibandingkan atribut lainnya. Secara keseluruhan leverage atribut sosial dapat dilihat pada Gambar 7.

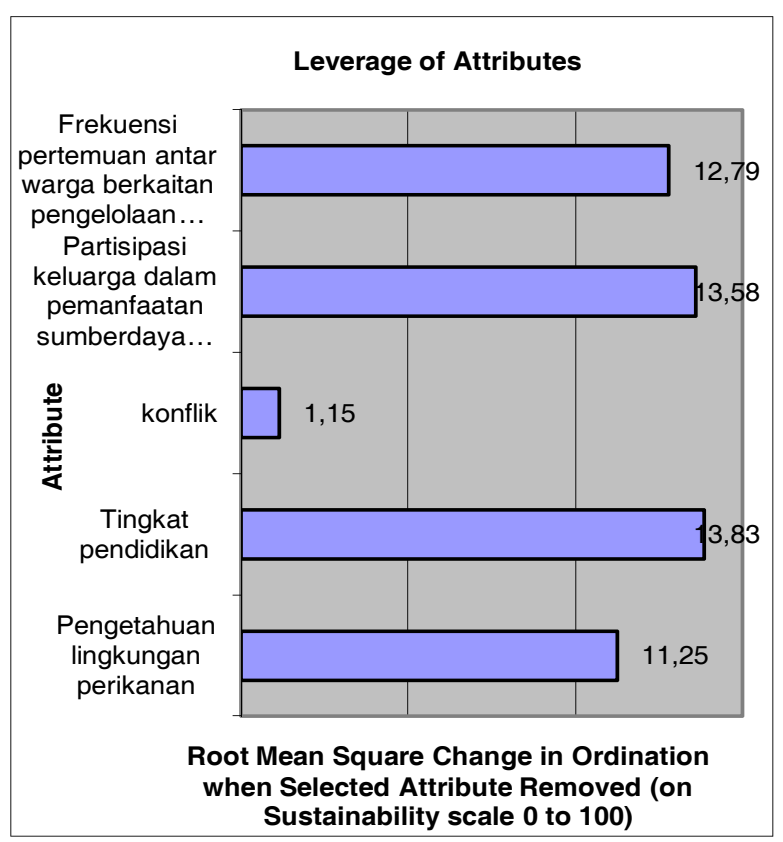

\section{Gambar 7. Analisis Distribusi Sensitivitas Atribut Pada Dimensi Sosial. \\ Figure 7. Attribute Sensitivity Distribution Analysis on Social Dimension.}

Atribut Tingkat pendidikan sangat sensitif dalam keberlanjutan pengelolaan budidaya ikan bandeng serta pertambakan lainnya karena faktor ini menentukan pola pemanfaatan dan tingkat degradasi lahan mangrove. Pola pemanfaatan terkait dengan teknologi yang dipilih dalam membudidayakan ikan bandeng. Serta pola penanganan limbah dan tingkat ekstensifikasi pertambakan. Sedangkan atribut Partisipasi keluarga dalam pemanfaatan sumberdaya perikanan juga sensitif dalam pengelolaan ini disebabkan faktor keterlibatan anggota keluarga dalam kegiatan usaha tambak di tingkat petambak sangat perlu untuk meminimalisir biaya tenaga kerja. Selain ini dari sisi sosial, partisipasi keluarga dalam menentukan pilihan pola pemanfaatan akan merata akan memudahkan terbentuknya kelompok masyarakat yang memiliki kebersamaan dalam pengelolaan sumberdaya perikanan berkelanjutan. 


\section{Teknologi}

Hasil analisis Monte Carlo dari dimensi sosial dapat dilihat pada Gambar 8. Hasil analisis tersebut menunjukkan bahwa usaha perikanan budidaya bandeng telah banyak mengalami gangguan (perturbation) yang ditunjukkan oleh plot yang menyebar.

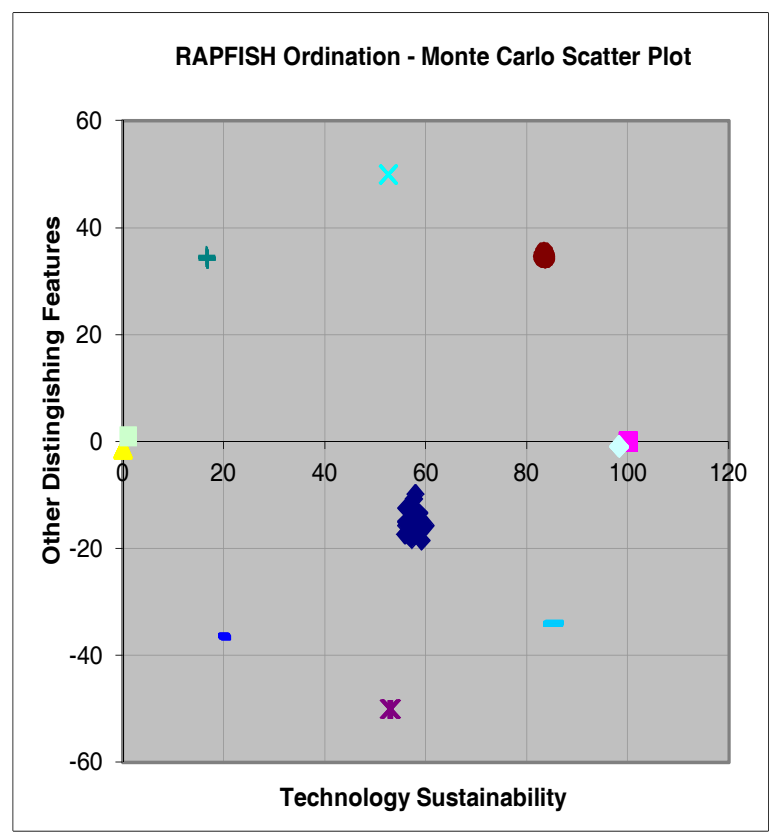

Gambar 8. Kestabilan Nilai Ordinasi Hasil Rapfish Dengan Monte Carlo Pada Dimensi Teknologi.

Figure 8. Stability of Rapfish Results Ordination Value With Monte Carlo in Technology Dimension.

Hasil analisis sensitifitas atau analisis leverage menggambarkan kondisi atributatribut teknologi yang digunakan perlu dianalisis atribut mana yang paling sensitif mempengaruhi tingkat keberlanjutan kegiatan perikanan budidaya bandeng menurut dimensi teknologi. Atribut sensitif dan perlu mendapat perhatian adalah ukuran tambak per petak (Gambar 9).

Atribut ukuran petak per tambak adalah faktor yang paling sensitif dalam menentukan keberlanjutan perikanan budidaya tambak. Kondisi ini sesuai dengan realitas dan teknologi yang diterapkan oleh kebanyakan petambak. Keberlanjutan pengelolaan perikanan budidaya bandeng akan efektif jika mencapai ukuran tambak ideal, sehingga efisiensi dapat tercapai.

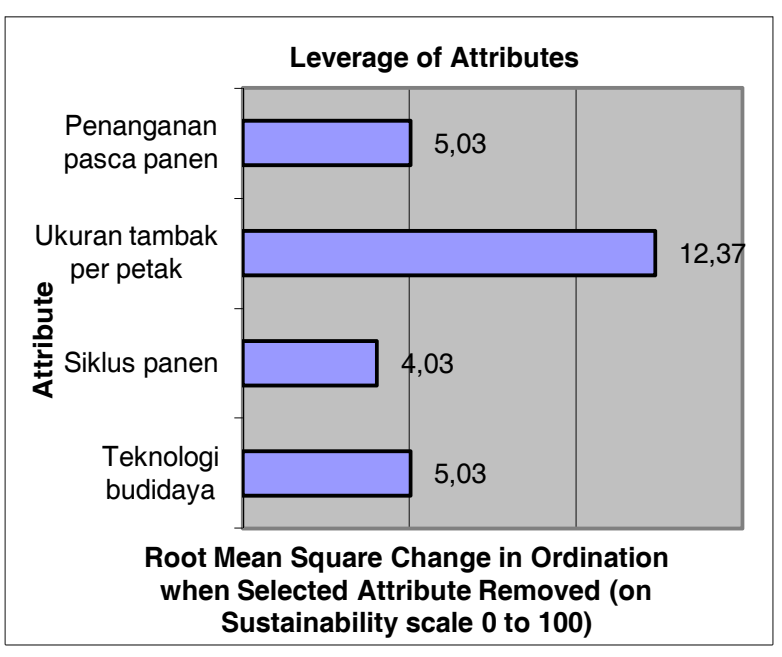

Gambar 9. Analisis Distribusi Sensitivitas Atribut Pada Dimensi Teknologi.

Figure 9. Attribute Sensitivity Distribution Analysis On Technology Dimension.

\section{Lembaga}

Hasil analisis Monte Carlo dari dimensi hukum/kelembagaan dapat dilihat pada Gambar 10. Hasil analisis tersebut menunjukkan bahwa usaha perikanan budididaya bandeng telah banyak mengalami gangguan (perturbation) yang ditunjukkan oleh plot yang menyebar.

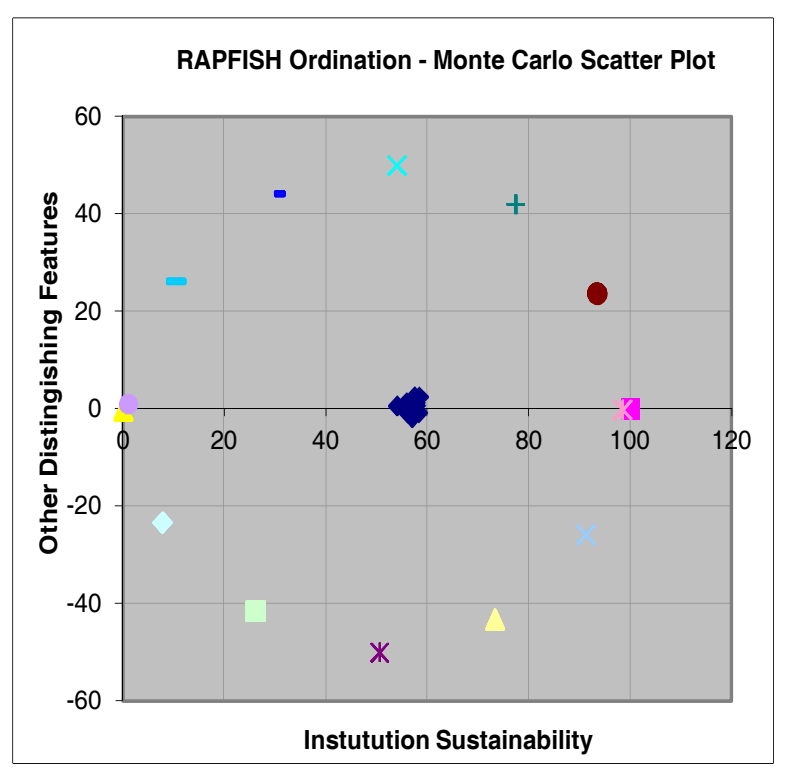

Gambar 10. Kestabilan Nilai Ordinasi Hasil Rapfish Dengan Monte Carlo Pada Dimensi Kelembagaan.

Figure 10. Stability of Rapfish Results Ordination Value With Monte Carlo in Institutional Dimension. 
Hasil Rapfish yang diperoleh menggambarkan kondisi secara umum berdasarkan penilaian atas atribut-atribut kelembagaan yang digunakan. Atribut-atribut kelembagaan yang digunakan tersebut perlu dianalisis atribut mana yang paling sensitif mempengaruhi tingkat keberlanjutan usaha perikanan budidaya bandeng menurut dimensi kelembagaan. Oleh karena itu diperlukan analisis sensitivitas atau analisis leverage. Secara keseluruhan leverage atribut kelembagaan dapat dilihat pada Gambar 11.

Upaya menuju keberlanjutan pengelolaan perikanan budidaya bandeng berdasarkan dimensi kelembagaan lebih ditentukan oleh atribut ketersediaan dan peran tokoh masyarakat lokal. Dapat dipahami, bahwa masyarakat pesisir umumnya memiliki kearifan lokal dan budaya menokohkan seseorang atau kelompok yang menjadi panutan. Pendekatan ketokohan ini akan efektif mengarahkan pada pengelolaan yang berkelanjutan jika ketersediaan tokoh masyarakat maupun pemberian peran dan pengetahuan dalam pengelolaan sumberdaya yang berkelanjutan.

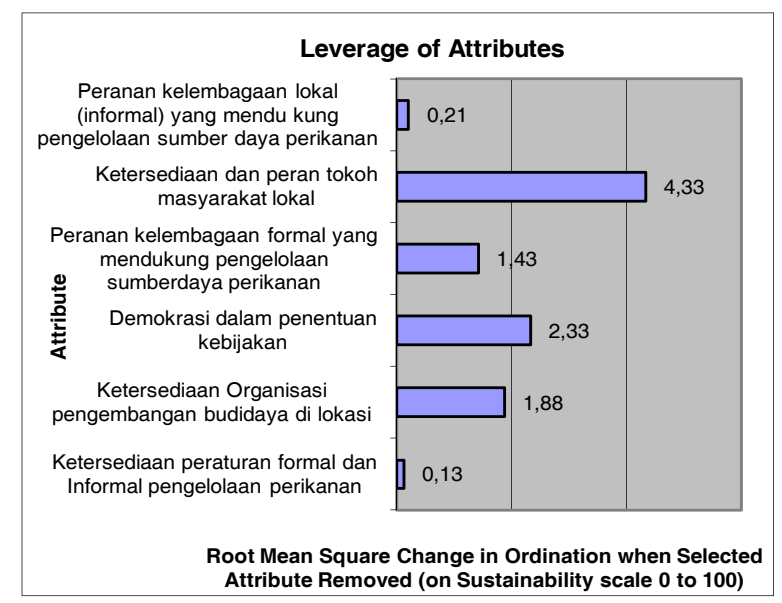

Gambar 11. Analisis Distribusi Sensitivitas Atribut Pada Dimensi Hukum dan Kelembagaan.

Figure 11. Attribute Sensitivity Distribution Analysis on Law and Institutional Dimension.

\section{Status Keberlanjutan Pengelolaan Perikanan Budidaya Bandeng}

Status keberlanjutan pengelolaan perikanan budidaya bandeng dinilai dari indeks hasil olahan rapfish. Umumnya penilaian indeks tersebut dikategorikan menjadi buruk (nilai indeks <50), sedang/cukup (nilai indeks 51-75), baik (nilai indeks > 76).
Status keberlanjutan pengelolaan perikanan budidaya bandeng secara umum berada pada status cukup/sedang dengan kecenderungan buruk. Tidak satupun dimensi yang diukur berada pada kategori baik. Dimensi Teknologi (57.55), Kelembagaan (56.78) dan Sosial (52.92) adalah dimensi dengan kategori cukup/sedang. Sedang dimensi Ekonomi (43.11) dan Ekologi (33.77) berada pada kategori keberlanjutan yang buruk.

Analisa diatas memperlihatkan pengelolaan perikanan budidaya bandeng perlu penanganan yang terarah. Dengan tingkat keberlanjutan ekologi dan ekonomi yang rendah, sudah semestinya pemerintah mengambil langkah strategi yang terpadu. Orientasi pengelolaan untuk meninjau keberlanjutan perikanan budidaya bandeng lebih mengutamakan perhatian pada aspek ekologi dan ekonomi. Adapun strategi yang dalam pengelolaan menuju keberlanjutan dengan mengurangi tekanan terhadap lingkungan (mangrove), serta dengan memperbanyak lokasi tujuan pemasaran atau orientasi pemasaran perikanan bandeng yang lebih memberi keuntungan bagi petambak.

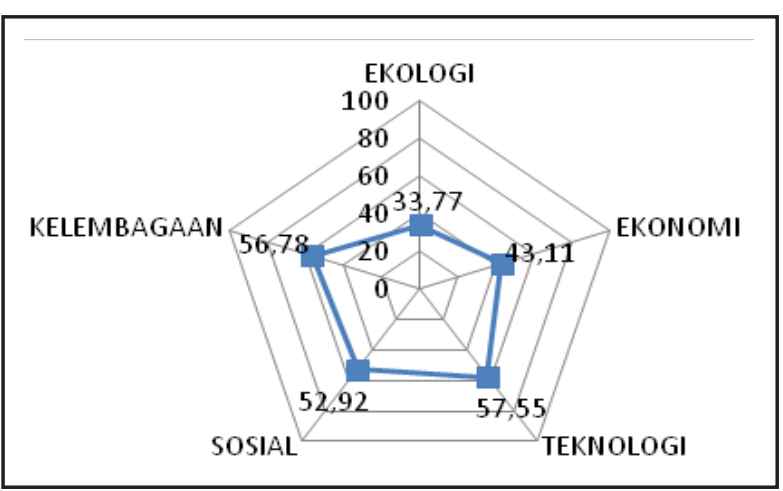

Gambar 12. Diagram Layang Nilai Status Keberlanjutan Perikanan Budidaya Bandeng.

Figure 12. Value Sustainability Status of Bandeng Aquaculture.

\section{KESIMPULAN DAN IMPLIKASI KEBIJAKAN}

\section{Kesimpulan}

Perikanan budidaya bandeng perlu reorientasi pengelolaan. Tujuan pengelolaan tidak cukup pada meningkatan kesejahteraan petambak melalui peningkatan produksi dan mutu ikan bandeng. Namun, memperhatikan keseimbangan ekologis dan ekonomi. 
Peningkatan dimensi ekologi pada reorientasi pengelolaan perikanan budidaya bandeng dapat melalui upaya mengurangi tekanan pada ekosistem mangrove dengan kegiaran rehabilitasi.

Upaya peningkatan ekonomi, lebih diutamakan melakukan memperbanyak tujuan pasar dan orientasi pemasaran ikan bandeng, dengan demikian nilai tambah produk perikanan dapat lebih memberi manfaat ekonomi yang lebih optimal.

\section{Implikasi Kebijakan}

Perlunya kebijakan multi sektor dalam pengelolaan mangrove. Pembukaan lahan mangrove untuk fungsi pemanfaatan perlu diperhatikan secara serius, melakukan tata kelola limbah tambak.

Perlunyakebijakan untukinovasi pasar produk perikanan bandeng dengan tidak mengekspor bahan baku, namun pada produk bernilai tambah (produk olahan).

\section{UCAPAN TERIMA KASIH}

Terimakasih penulis ucapkan kepada Pemerintah Daerah Kabupaten Sidoarjo serta Kabupaten Gresik atas diskusi pengembangan budidaya ikan bandeng, semoga usaha bandeng makin maju dan pembudidaya semakin sejahtera. terimakasih pula penulis ucapkan kepada teman-teman peneliti di Balai Besar Penelitian dan Pengembangan Budidaya Laut di Gondol, Bali. serta teman peneliti di Pusat Penelitian Sosial Ekonomi Kelautan dan Perikanan atas diskusi pengembangan tulisan dan saran-saran membangun lainnya.

\section{DAFTAR PUSTAKA}

Alder, J., D. Zeller, T. Pitcher and R. Sumalia. 2002. A Method for Evaluating Marine Protected Area Management. Coastal Management Journal, 30 (2): 121-131.

Alder, J., T.J. Pitcher, D. Preikshot., K.Kaschner and Ferriss. 2000. How Good is Good ?: A Rapid Appraisal Technique for Evaluation of The Sustainability Status of Fisheries of The North Atlantic. In D. Pauly and T.J. Pitcher (Editors). Methods for Evaluating The Impacts on North Atlantic Ecosystems. Fisheries Center Report. Fisheries Center, Univ. Of British Columbia, Vancouver.
Badan Pusat Statistik Kabupaten Gresik. Kantor BPS Kabupaten Gresik, 2014. Gresik Dalam Angka 2015.

Dinas kelautan, perikanan dan peternakan Kabupaten Gresik, 2013. laporan tahunan Dinas Kelautan, Perikanan dan Peternakan Kabupaten Gresik.

FAO. 2001. Indicators for Sustainable Development of Marine Capture Fisheries. FAO Technical Guidelines for Responsible Fisheries. No. 08 Food and Agriculture Organization (FAO) Rome.

Fauzi, A. dan S. Anna. 2002a. Evaluasi Status Keberlanjutan Pembangunan Perikanan : Aplikasi Pendekatan Rapfish (Studi Kasus Perairan DKI Jakarta). Jurnal Pesisir dan Lautan Vol. 4 (3). pp: 43-55.

Kavanagh, P. 2001. Rapid Appraisal Of Fisheries (Rapfish) Project : Rapfish Software Description (For Microsoft Excel). University of British Columbia, Fisheries Centre, Vancouver.

Pitcher, T. J., A. Bundy, D. Preikshot, T. Hutton, and D. Pauly. 1998. Measuring The Unmeasurable: A Multivariate And Interdisciplinary Method For Rapid Appraisal Of The Health Of Fisheries. Dalam T. J. Pitcher, P. Hart, dan D. Pauly (editor): Reinventing Fisheries Management. Kluwer, London.

Pitcher, T.J. and D. Preikshot. 2001. RAPFISH : A Rapid Appraisal Technique to Evaluate The Sustainability Status of Fisheries. Fisheries Research Report, Fisheries Center University of British Columbia, Vancouver.

Susilo, S. B. 2003. Keberlanjutan Pembangunan Pulau-Pulau Kecil : Studi Kasus Kelurahan Pulau Panggang dan Pulau Pari, Kepulauan Seribu, DKI Jakarta. Disertasi. Program Pascasarjana Institut Pertanian Bogor. Tidak dipublikasikan. 